\title{
The Dynamics of Ports Reforms in Nigeria: Implications for Sustainable Ports Operations
}

\author{
${ }^{1,2}$ LAWANI, A. O. AND $\quad{ }^{2}$ D. BADEJO \\ 1.Federal College of Education, PMB 2096, Abeokuta, Ogun State, Nigeria \\ 2.Department of Geography and Regional Planning Centre For Transport Studies, Faculty of Social Sciences \\ Olabisi Onabanjo University Ago-Iwoye, Ogun State
}

\begin{abstract}
Over the time Nigeria economy is largely public sector driven, in which the seaports were not left out: managed by Nigerian Port Authority (NP A). With the seaports under the autonomous of NPA were faced with strangulating problems ranging from inefficiency of it services rendered, insecurity of ships and cargo, lack of modern infrastructures, inefficiency of the NPA staff and excess bureaucracy and sharp practice (corporate) these factors make port tariff on import and export higher than they need to be, couple with the technology trend in maritime transport which required huge capital fund. The government call for ports reforms; a reform that will liberalized and deregulate the seaport by the use of concession contract, this mandate the NPA to transfer terminals operators while NPA concentrates to play the role of landlord oversight functions. The government went further to reform the import guidelines procedures and documentation requirement, changing it form Preshipment Inspection (PSI) to Destination Inspection (DI). The Seaport reforms which government introduced in 1996 eliminated the crippling delays in the clearance of import goods in the ports. This research study will examine the dynamics of port operations, the contribution of private operator in seaport operations, and services; technological development: considering the variable attached to seaport operations. Furthermore, this research analyze private sector capital investment in port and maintenance of infrastructures, superstructures and the contract of concession with other practicing nations, while from drawn questionnaire and secondary data the research will examine how and if Nigeria will benefit in the area of capacity building, physical development and if at all there is competition among the terminal operators considering there role in the concession regime. Finally, emphasis and comparison will be laid on cargo throughout, ship tum around, clearing procedures and port charges with the involvement of private participation.
\end{abstract}

DOI: $10.7176 / \mathrm{PPAR} / 11-7-01$

Publication date:August $31^{\text {st }} 2021$

\section{INTRODUCTION}

The Federal Government of Nigeria, through Nigerian Ports Authority (NPA) has over the years made huge investment in the development of ultra-modern port complexes designed to cope with challenges posed by modem shipping technology in doing this, Nigerian seaports are managed and administered as a state owned ports under the coordination of NPA. Sincerely speaking the Nigeria economy over the time has been largely public sector driven in which the Federal Government's has invested over $\$ 100$ billion in the public investment. From the beginning of seaport operation, administration and management in Nigeria, ports are runs on the bases of traditional in which government see to the running of seaports through port authority. In this mode of administration, the regulatory activity of government in port has two dimensions. First, the safety, environmental issues and quality of ports services. The second dimension is the economic regulation of private port operators where they exist. In Nigeria, port reform is not new, in 1992 the government's efforts to ensure the efficiency and profitability of public enterprises, the Federal government commercialized the Nigerian Port Authority. In February, 1996, the federal government introduced the port reforms to check fraud, enhance revenue collecting and eliminate the crippling delays in the clearance of goods. The highlights of the reforms include Mandatory Import Duty Report (IDR) covering cargoes irrespective of value, the introduction of Professional Import Duty Administrator (PIDA) into port to assist custom to collect import duties. The government intention was aimed at increasing port activities for increased revenue generation. In summary, the 1996 reform, government had to slash port tariff and import duties by about 70 and 30 percent respectively to underscore its determination to cargo but the users considered the nation's port expensive due to the demand of IDR and additional cost of paying Pre -shipment inspection agent fees and extortion tendency of some security agencies. The problem and bore of contention of the reforms continues when the port users complains of activities PIDA that has not really assist to achieve the 48 hours goods clearance but has duplicated the functions of custom revenue collection. Ironically, in 1996 seaport reforms, the volume of containerized and other cargoes dropped drastically, the Tin Can and Apapa port was characterized by low level of port activities, due to reduction in the number of vessels into the ports. Then considering above problem facing the nations seaport, the government had been looking for a way to achieve best port practice in Nigeria. In long run, a newly designed ports reform was introduced in year 2004 which call for private investors in port operations and services. Really this type of port organisation can be 
found around the world; presently port reform globally is practiced, either through privatization, commercialization or port concession. Before now, within the European Countries, however a plan to create a self-financing port system that would not receive subsides from government (European Commission, 1997). However, due to technological trend in the maritime transport in the past decades, which are irreversible and affect port operation globally, these basic technology innovations in the transportation of cargo, the most remarkable are the containerization of cargo and the development of large specialized ships, this revolution have forced seaports authority to facilities renovations to serve the new technology development, this call for government the needs to finance infrastructures renovation and building new facilities to achieve better efficiency rate of the ports, toward this trend, intensive capital project will be required through funding, to meet the challenges, Nigeria government sees the seaports as a big drain of public funds, while some described it as failed investment having been unable to attain the objectives for which they were set-up in the first instance, in summary the present government felt something must be done to the nation seaports to save the government from non-profitable investment. Okpa (1993) explained that the Federal government focus to reduce public expenditure, and to avoid a situation in which port facilities deteriorate while operating cost escalate with unexpected breakdowns. So it consider it economically prudent and financially expedient to encourage private sector participation in consonance with contemporary practice all over the world, thereby shifting emphasis from government driven to private sector driven economy. Badejo (2000) in his study said before port concession, that countries run their port as government agencies, and that they are not managed as business entities capable of generating profit. Furthermore, that government provide the required capital, administration policy framework, monitoring, control, funding human and capital response, as a result port administration and management became bureaucratic, inefficient and ineffective. Moreso, ports were over-staffed while operating infrastructures became obsolete, coupled with poor maintenance. The implication of the above reasons resulted into port congestion, poor port services, cargo diversion to neighbouring seaports, and even security (pilferage).

The government considered over mentioned problems facing the entire maritime transport industry through the seaports, and so the Nigeria government opted not for privatization, or commercialization but contractual port concession. Privatization which connotes an outright sale which does not appear to be government intention. The states intention or option appear to be the landlord port model, where the NPA is both the owner as well as the regulating body. The model entails ownership remaining with government but while the ports services concessioned out to private sector operator. It is however imperative to study the objective of concession, the rehabilitation plan of the concessionaires, problem shared by many ports worldwide, the risk shared among the port authority (landlord) and the concessionaires and if really seaport concession promote competition among port of regional level.

It should noted that ports are but one link in the international trading system and that care should be taken to ensure that reform extends beyond the port itself. For future purpose, sustain port operation and activities by private participation may be used to determine if any role should be retained by the public sector to sustain the economic development and what restriction or limits should be placed on private operators, what safeguards are needed to prevent any abuse. Furthermore, this research will exclusive study the services of concessionaires how it promote economic efficiency, preserving and protecting the public interest in viable port system and thus to know that private participation in seaport operation in certain circumstances hold of stimulating economic growth and higher standard of living of the society at large as well as those whose livelihood depends directly on port activity and trade.

\section{AIMS AND OBJECTIVES OF THE STUDY}

1. To critically examine how port concession affects the operations and services of port.

2. To examine if there is improvement in the management and organization development in Nigerian Port Authority.

3. To examine how concessionaires carries out port operations and services.

4. To appraise the level of security strategies and outfit in the port before and after port reforms.

5. To examine the terms of contract and exclusive the use of infrastructures and superstructures port facilities (assets).

6. To highlight the general problem inhibiting against the success of port concession.

7. To examine if the port reforms encourage or discourage competition.

\section{DATA SOURCES}

Basically there are two sources through which data and information were collected, viz: the primary and the secondary sources.

\section{STUDY AREA}

As at today, there are twelve (12) seaport in Nigeria, excluding the oil terminals and jetties with a cargo 
handling capacity of over 35 million tonnes, under the supervision of Nigerian Ports Authority (NPA). The ports which are located in zones, see table below.

TABLE 1: Seaports in Nigeria

\begin{tabular}{|l|l|l|}
\hline ZONE & PORTS & HEADQUARTERS \\
\hline Western Zone & Apapa Port, Tin Can Port, Apapa Port, Tin Can Port, & Apapa, Lagos \\
\hline Central Zone & Warri Port (Old \& New Port) Sapele, Koko, Burutu & Warri \\
\hline Eastern Zone & $\begin{array}{l}\text { Port Harcourt Port, Federal Lighter Terminal, Onne, } \\
\text { Federal Ocean Terminal, Onne, Calabar Port }\end{array}$ & Port Harcourt \\
\hline
\end{tabular}

Source: Badejo, 1998

This research study area will cover the ports in western zone of the country (Nigeria), comprises of four ports located in Apapa port complexes of Lagos. These port complexes which handles about 80 percent of Nigeria's total sea-borne trade. The Apapa port complex consist of Apapa quays, that cover a land area of about 100 hectares, with total quay length of 2,459 metres capable of handling about 20 ships at a time. The third Apapa port extension has a quay length of 1,500 metres and specially designed to handle ship with a greater draft of about 10.50metres. The Tin Can Island port which was built to ease the traffics congestion problems at Apapa port complex. This port has fourteen berths with a total quay length of 2,500metres and a draft of 9.50 metres. Seven of the berths are for break bulk general cargo while two are RoRo (Roll-on-Roll-off) berths and one dry bulk cargo berth. The port all together can accommodate sixteen vessels at a time, having five transit sheds of 34,000 square metres space, three warehouses of 24,000 square metres space.

TABLE Il: Concessionaires and their respective ports/terminal of operations

\begin{tabular}{|l|l|}
\hline \multicolumn{1}{|c|}{ PORTS } & \multicolumn{1}{c|}{ CONCESSIONAIRES } \\
\hline Tin Can Island Apapa, Lagos & Five Star Logistics Ltd \\
& Ports and Cargo Ltd \\
& Tin Can Island container Terminal \\
\hline Apapa Port Lagos & ENL Consortium Ltd \\
& A.P Moller \\
& Greenview Development Nig. Ltd \\
& Apapa Bulk Terminal Ltd (ABTL) \\
\hline Warri Port (Old Terminal) & AMS Nig Ltd \\
\hline Port-Harcourt Port & Intel Nig Ltd \\
& Sifax Group \\
\hline $\begin{array}{l}\text { Federal Ocean } \\
\text { Terminal (FOT) }\end{array}$ & Intel Nig. Ltd \\
(Onne) Port-Harcourt & \\
\hline $\begin{array}{l}\text { Federal Ocean Terminal } \\
\text { (FLT Onne, Port-Harcourt }\end{array}$ & Intel Nig Ltd \\
\hline Calabar Port & Ecomarine Consortium Ltd \\
\hline
\end{tabular}

Source: NPA Western Anchore, 2006.

\section{NIGERIAN PORTS AUTHORITY OPERATIONAL ACTIVITIES}

By definition, Weigend (1958) defines a port as a place of contact between land and maritime space. He further said, a port is a knot where ocean and inland transport line meet and inter wine. The primary function of a port according to Weigend is to transfer goods and passengers from ocean vessels traffics, therefore meaning the life and prosperity of a seaport. Similarly to the above definition, Taylor (1974) defined a seaport as a place to which ships resort to load and discharge cargoes, therefore port is regarded as an essential part and not an isolated unit of maritime transport system. Hence a nation strives to provide an efficient and cost effective port system, and to be effective in its operations and services the Nigerian Ports Authority (NPA), being supervised by the Federal Ministry of Transport has the following summarized statutory duties and major functions viz:

1. The provision, operation and management of cargo handling and quay facilities to service public interest.

2. To maintain, improve and regulate the use of the harbour.

3. The dredging of the harbour, it waterways to desire depth, pilotage and towage services.

4. To achieve and maintain a high level of labour productivity in all its operations to reduce the turn-around time of ship using the port facilities.

5. To ensure and maintain competatives operations, services and stable charges through the use of port facilities.

6. Checking and preventing marine pollution.

7. The supply of fresh water and bunkers for vessels.

8. The provision of navigational aids, lighting, light houses, buoys and

9. Other ancillary services. 
AVAILABLE NUMBER AND FUNCTIONING NPA PLANTS \& EQUIPMENT

The efficient ports operations services and an improvement on tum around time of vessel is dependent and a function of availability of adequate cargo handling equipment. Therefore, the importance of adequate cargo handling equipment in any seaport cannot be over-emphasized. In this research work, emphasizes will be laid on the data from the NPA, Annual Report, of the cargo handling equipment procured over 10 years ago, to meet the challenges of shipping technology and competition from neighbouring countries. The equipment. are available before private investors take over the ports / terminals.

Table Il: Nigerian Port Authority Equipment and Plants

\begin{tabular}{|l|l|ll|}
\hline Type & Total Number of fleet & $\begin{array}{l}\text { Functioning } \\
\text { Condition) }\end{array}$ & $\begin{array}{c}\text { (Working } \% \text { functioning } \\
\text { Equipment }\end{array}$ \\
\hline Portal crane & 38 & 15 & 39.5 \\
\hline Mobile crane & 38 & 12 & 31.5 \\
\hline Gantry crane & 35 & 8 & 22.9 \\
\hline Forklift Truck & 222 & 69 & 31.0 \\
\hline Freight Lifter & 60 & 15 & 25.0 \\
\hline Straddle Carrier & 6 & 4 & 66.7 \\
\hline Trailer & 99 & 29 & 29.3 \\
\hline Container Handlers & 48 & 21 & 43.8 \\
\hline Locomotive Engine & 9 & 7 & 77.8 \\
\hline Others & 18 & 7 & 38.9 \\
\hline Total & 573 & 187 & 32.6 \\
\hline
\end{tabular}

Source: Nigerian ports Authority, Annual Report

From the represented figures in table III, it shows types of cargo handling equipment available at Nigeria seaports. Though, there are other equipment, but the above table III were those which meant for cargo handling in the ports. From figure analysis, the total number of 573 fleet (both serviceable and non-serviceable), of which only 187 fleet are in working condition, thus 32.6 percent

Furthermore, an important cargo handling equipment which cannot be compromised in the area of lifting and stacking of container is the straddle carrier, in which 4 were in good working condition out of available 6 for such purpose.

Similarly, the percentage of portal crane, mobile crane and the forklifts in the table III represented as 39.5, 31.5 and 31.0 percent respectively. Considering the data from the Table III, shows that none of the cargo handling equipment attained 50 percent except straddle carrier and locomotive engine with 66.7 and 77 percent respectively.

\section{RESULTS AND DISCUSSION}

\section{CARGO THROUGHPUT IN RORO PORT}

The cargo throughput which comprises of the imports and export cargo RORO Port, this includes containers vehicles and general cargoes. By definition, cargo throughput is the total inward plus outward traffic handled in port within a given period. Cargo throughput can be equal to import and export, if the port in question does not handles any domestic traffic. The RORO Port recorded a total of cargo throughput of 6,220,721 tonnes from the year (1996 - 2005), out which container contributed 4,014,662 tonnes representing 64.5 percent, while vehicle traffic and general cargo contributed $1,896,161$ and 309,898 with 30.5 and 4.99 percent of the total cargo throughput.

Table VI: Cargo throughput in RORO Port from 1996 -- 2005

\begin{tabular}{|l|l|l|l|}
\hline PERIOD & $\begin{array}{c}\text { CONTAINER IMPORT \& } \\
\text { EXPORT (TON }\end{array}$ & $\begin{array}{c}\text { VEHICLE IMPORT \& } \\
\text { EXPORT (TON) }\end{array}$ & $\begin{array}{c}\text { GENERAL CARGO IMPORT } \\
\text { \& EXPORT (TON) }\end{array}$ \\
\hline 1996 & 286,888 & 33,704 & 23,493 \\
\hline 1997 & 310,991 & 29,871 & 37,953 \\
\hline 1998 & 314,406 & 54,526 & 22,759 \\
\hline 1999 & 384,256 & 111,970 & 48,686 \\
\hline 2000 & 556,828 & 203,740 & 39,299 \\
\hline 2001 & 492,631 & 461,148 & 29,468 \\
\hline 2002 & 462,113 & 316,771 & 24,669 \\
\hline 2003 & 353,426 & 237,629 & 31,116 \\
\hline 2004 & 403,728 & 311,942 & 27,513 \\
\hline 2005 & 449,395 & 134,860 & 22,942 \\
\hline TOTAL & $4,014,662$ & $1,896,161$ & 309,898 \\
\hline
\end{tabular}

Source: Nigeria Ports Authority, Annual Report 


\section{SHIPS TURN AROUND TIME}

In carrying out this research work, data were collected through secondary sources from Nigeria Ports Authority. Annual reports on the following arrears.

1. Available and funding cargo handling equipment (both serviceable and non-serviceable).

2. Turn around time of vessels at RORO Port, and

3. Cargo throughput in RORO Port.

From definition, the ship turn around time which is the time taken by a ship in the process of entering the port, discharging her cargo and / or loading and leaving the port. This time which is very important, hence it should be kept at a minimum so that Nigeria seaports can be in competitive with other seaports globally, and especially with neighbouring seaports.

Table Vll: Ships turn around time (in Days) of Vessels in RORO Port (2000 --2004)

\begin{tabular}{|l|l|l|l|}
\hline PERIOD & $\begin{array}{l}\text { AVERAGE WAITING } \\
\text { TIME }\end{array}$ & $\begin{array}{l}\text { AVERAGE SERVICE } \\
\text { TIME }\end{array}$ & $\begin{array}{l}\text { AVERAGE } \\
\text { AROUND TIME }\end{array}$ \\
\hline 2000 & 0.08 & 1.53 & 1.61 \\
\hline 2001 & 0.25 & 2.57 & 2.82 \\
\hline 2002 & 0.09 & 1.55 & 1.64 \\
\hline 2003 & 0.19 & 1.56 & 1.70 \\
\hline 2004 & 0.17 & 1.63 & 1.80 \\
\hline
\end{tabular}

Source: Nigerian Ports Authority Annual Report

Based on the figure in the table VII, the port average ship turn around time of vessel was 1.91 days meaning that ship that call at the port stays a minimum of 1.91 days for service to be rendered.

\begin{tabular}{|c|c|c|c|c|c|c|c|c|}
\hline \multirow[t]{2}{*}{ MONTH } & \multirow{2}{*}{$\begin{array}{l}\text { NO OF } \\
\text { CHIPS } \\
\text { CLEARED }\end{array}$} & $\begin{array}{l}\text { NO OF } \\
\text { SPENT }\end{array}$ & DAYS & \multirow[t]{2}{*}{ WORKING } & \multirow{2}{*}{$\begin{array}{l}\text { AVERAGE } \\
\text { WAITING } \\
\text { TIME }\end{array}$} & \multirow[t]{2}{*}{$\begin{array}{l}\text { AVERAGE } \\
\text { IDLE TIME }\end{array}$} & \multirow{2}{*}{$\begin{array}{l}\text { AVERAGE } \\
\text { WORKING } \\
\text { TIME }\end{array}$} & \multirow{2}{*}{$\begin{array}{l}\text { AVERAGE } \\
\text { TURNING } \\
\text { ROUND } \\
\text { TIME }\end{array}$} \\
\hline & & WAITING & IDLE & & & & & \\
\hline JANUARY & 13 & 14 & 6.5 & 26.2 & 0.1 & 0.5 & 2.0 & 2.6 \\
\hline FEBRUARY & 17 & 2.6 & 4.1 & 27.3 & 0.1 & 0.2 & 1.6 & 1.9 \\
\hline MARCH & 15 & 1.9 & 8.8 & 25.3 & 0.1 & 0.5 & 16 & 2.2 \\
\hline APRIL & 19 & 2.5 & 7.1 & 43.3 & 0.1 & 0.2 & 2.2 & 2.5 \\
\hline MAY & 24 & 2.4 & 8.4 & 63.2 & 0.1 & 0.3 & 2.6 & 3.0 \\
\hline JUNE & 19 & 1.9 & 4.1 & 53.7 & 0.1 & 0.2 & 2.8 & 3.1 \\
\hline JULY & 15 & 1.6 & 6.0 & 28.0 & 0.1 & 0.4 & 1.9 & 2.4 \\
\hline AUGUST & 17 & 2.5 & 21.2 & 20.6 & 0.1 & 1.2 & 1.2 & 2.5 \\
\hline SEPTEMBER & 19 & 2.0 & 11.7 & 41.7 & 0.1 & 0.6 & 2.2 & 2.9 \\
\hline OCTOBER & 17 & 2.2 & 5.7 & 31.5 & 0.1 & 0.3 & 1.8 & 2.2 \\
\hline NOVEMBER & 13 & 1.7 & 6.8 & 26.7 & 0.1 & 0.5 & 2.0 & 2.6 \\
\hline DECEMBER & 18 & 2.3 & 7.7 & 34.6 & 0.1 & 0.4 & 1.9 & 2.4 \\
\hline TOTAL 2004 & 206 & 25.0 & 98.1 & 422.1 & 0.1 & 0.4 & 2.0 & 2.6 \\
\hline
\end{tabular}

Table VIII: Ships turnaround time (in days), 2004

\section{HYPOTHESES OF THE STUDY}

The major hypothesis to be tested in this research are: NULL HYPOTHESES (GENERAL)

1. That the Nigeria Ports Authority (NP A) staff were not well placed in the reform.

2. No meaningful physical development were carried out by the private investors

3. That there is no need for security network at port re-organised or totally replaced

4. That there is no need for more private sector involvement in port operations and services,

5. There has been no any remarkable improvement in the operations by the concessionaires. 
Table IX: Distribution \& Collection of Questionnaires

\begin{tabular}{|l|l|l|l|l|}
\hline S/N & DISTRIBUTED & RETURN & \% OF RETURNED \\
\hline 1 & Nigeria Port Authority & 200 & 192 & 96 \\
\hline 2 & Five Staff Logistics Ltd. & 10 & 10 & 100 \\
\hline 3 & Ports \&Cargo Ltd. & 10 & 10 & 100 \\
\hline 4 & Tin Can Island Container Terminal & 20 & 20 & 100 \\
\hline 5 & ENL Consortium Limited & 10 & 10 & 100 \\
\hline 6 & APMoller & 20 & 19 & 95 \\
\hline 7 & Greeview Department Nig .Ltd. & 10 & 10 & 100 \\
\hline 8 & Apaja Bulk Terminal Ltd. & 20 & 18 & 90 \\
\hline 9 & Cotecna Inspection Limited. & 50 & 44 & 88 \\
\hline & TOTAL & 350 & 333 & 95.14 \\
\hline
\end{tabular}

Source: Author 'sfield work, 2008

Question One

What is your position (official designation)

\begin{tabular}{|l|l|}
\hline Managing Director & 4 \\
\hline Snr. Executive manger Director & 16 \\
\hline Jnr. Managers & 24 \\
\hline Snr. Staff & 92 \\
\hline Jnr. Staff & 197 \\
\hline Total & 333 \\
\hline
\end{tabular}

Source: Author'sfield work, 2008

Question Two:

How long have you been in the maritime/shipping industry?

\begin{tabular}{|c|c|c|}
\hline Option & Response & Percentage \\
\hline $1-5$ years & 52 & 15.62 \\
\hline 6- 10 years & 43 & 12.91 \\
\hline $11-15$ years & 117 & 35.13 \\
\hline 16 and above & 121 & 36.34 \\
\hline Total & 333 & 100 \\
\hline
\end{tabular}

Source: Author'sfield work, 2008

Question Three:

Are you satisfies with the present state of port infrastructures and superstructure in the port?.

\begin{tabular}{|c|c|c|}
\hline Option & Response & Percentage \\
\hline Yes & 92 & 31.83 \\
\hline No & 197 & 68.17 \\
\hline Total & 289 & 100 \\
\hline
\end{tabular}

Question Four

Source: Author's field work, 2008

Are your familiar with the recent port reforms

\begin{tabular}{|l|l|l|}
\hline Option & Response & Percentage \\
\hline Yes & 171 & 89.06 \\
\hline No & 21 & 10.94 \\
\hline Total & 192 & 100 \\
\hline
\end{tabular}

Source: Author's field work, 2008

Question Five:

From your assessment how will you rate operational performance of the private sector?

\begin{tabular}{|l|l|c|}
\hline Option & Response & Percentage \\
\hline $10-30 \%$ & NIL & NIL \\
\hline $31-50 \%$ & 104 & 54.17 \\
\hline $51--70 \%$ & 67 & 34.90 \\
\hline 71 and above & 21 & 10.93 \\
\hline Total & 192 & 100 \\
\hline
\end{tabular}

Source: Author's field work, 2008 
Question Six:

Did your organization is able to get skilled and qualified staff for your operation and services?

\begin{tabular}{|l|l|c|}
\hline Option & Response & Percentage \\
\hline Yes & 76 & 73.35 \\
\hline No & 21 & 21.65 \\
\hline Total & 97 & 100 \\
\hline
\end{tabular}

Source: Author's field work, 2008

Question Seven:

Has your organization carried out any physical infrastructure, or superstructure development?

\begin{tabular}{|c|c|c|}
\hline Option & Response & Percentage \\
\hline Yes & 78 & 80.41 \\
\hline No & 19 & 19.59 \\
\hline Total & 97 & 100 \\
\hline
\end{tabular}

Source: Author's field work, 2008

Question Eight:

Is there any training package for your staff

\begin{tabular}{|l|c|c|}
\hline Option & Response & Percentage \\
\hline Yes & 91 & 93.81 \\
\hline No & 6 & 6.19 \\
\hline Total & 97 & 100 \\
\hline
\end{tabular}

Source: Author's field work, 2008

Question Nine:

Presently, how is the rate of pilferage in the port

\begin{tabular}{|c|c|c|}
\hline Option & Response & Percentage \\
\hline Yes & 91 & 87.69 \\
\hline No & 6 & 12.31 \\
\hline Total & 97 & 100 \\
\hline
\end{tabular}

Source: Author's field work, 2008

\section{HYPOTHESES TESTING}

HYPOTHESIS ONE

$\mathrm{H}_{\mathrm{o}}$ : That the Nigerian Port Authority (NPA) staff were not well placed in the port reforms

$\mathrm{H}_{1}$. That the Nigerian Port Authority (NPA) staff were well placed in the reform

Question Ten:

Were the Nigerian Port Authority (NPA) staff well placed in the reform?

Table 4.1

\begin{tabular}{|l|l|l|}
\hline Option & Response & Percentage \\
\hline Yes & $26(96)$ & 15.54 \\
\hline No & $166(96)$ & 84.46 \\
\hline Total & 192 & 100 \\
\hline
\end{tabular}

Source: Author's field work, 2008

Table 4.1: shows that 84.46 percent of NPA staff responded that the government does not considered the staff Nigerian Port Authority in the Port reforms

The bracket number in table 4.1 represent the expected frequencies. The expected frequency $(\mathrm{E})=\mathrm{EX} / \mathrm{n}$

$$
=192 / 2=96
$$

Therefore, the data as in table 4.1 can be re-arranged to reflect the observed frequency (0), expected frequency $(\mathrm{E})$, deviation $(\mathrm{O}-\mathrm{E})$ and square deviation $(0-\mathrm{E})^{2}$

Table 4.2

\begin{tabular}{|l|l|l|l|l|l|}
\hline Options & $\mathrm{O}$ & $\mathrm{E}$ & $\mathrm{O}-\mathrm{E}$ & $(\mathrm{O}-\mathrm{E}) 2$ & $\mathrm{X} 2=(\mathrm{O}-\mathrm{E}) 2 / \mathrm{E}$ \\
\hline Yes & 26 & 96 & -70 & 4900 & 51.04 \\
\hline No & 166 & 96 & 70 & 4900 & 51.04 \\
\hline Total & 192 & & 0 & & 102.08 \\
\hline
\end{tabular}

Source: Author'sfield work, 2008

From table $4.2, \mathrm{X}^{2}$ calculated $=102.08$, to determine $\mathrm{X}^{2}$ from chi-square the table (Appendix V)

Degree of freedom $(m)=n-1$

$$
2-1=1
$$

Assuming 0.01 level of significant $\left(99 \%\right.$ confidence level) i.e $\mathrm{X}^{2}{ }_{(0.01)}=6.63$ (Appendix V) 
Decision Rule

Accept $\mathrm{H}_{\mathrm{o}}$ if $\mathrm{X}^{2}$ calculated $<\mathrm{X}^{2}$ table

Reject Ho $\mathrm{X}^{2}$ calculated $>\mathrm{X}^{2}$ table and accept the alternative hypothesis $\left(\mathrm{H}_{1}\right)$

\section{Conclusion}

Since computed $\mathrm{X}^{2}>\mathrm{X}^{2}$ of the chi-square table $(102.8>6.63)$. The null hypothesis $(\mathrm{Ho})$ is rejected to accept the alternative hypothesis which state that the Nigerian Ports Authority staff were well placed in the post reforms.

\section{HYPOTHESIS TWO}

Ho: No meaningful physical developments were carried out by the private investors.

$\mathrm{H}_{1}$ : Meaningful physical developments were carried out by the private investors

Question Eleven:

ls there any meaningful physical developments were carried out by the private investor in the port?

Table 4.3

\begin{tabular}{|l|l|l|}
\hline Option & Response & Percentage \\
\hline Yes & $14(96)$ & 7.29 \\
\hline No & $178(96)$ & 92.71 \\
\hline Total & 192 & 100 \\
\hline
\end{tabular}

Source: Author's field work, 2008

The 92.71 percent agree that no meaning physical development were caused out by the private investors

Based on this analysis, should one disagree with media publication that the private investors are putting on development to meet the trend of technology in the shipping business in their respective won terminals.

The bracket number in table 4.3 represent the expected frequencies. The expected frequency $(\mathrm{E})=\mathrm{EX} / \mathrm{n}$ $191 / 2=96$

The above data in table 4.3 can be re-arranged to show the observed frequency $(0)$, expected frequency (E), deviation $(0-\mathrm{E})$, square deviation $(0-\mathrm{E})^{2}$

Table 4.4

\begin{tabular}{|l|l|l|l|l|l|}
\hline Options & $\mathrm{O}$ & $\mathrm{E}$ & $\mathrm{O}-\mathrm{E}$ & $(\mathrm{O}-\mathrm{E}) 2$ & $\mathrm{X} 2=(\mathrm{O}-\mathrm{E}) 2 / \mathrm{E}$ \\
\hline Yes & 14 & 96 & -82 & 6724 & 70.04 \\
\hline No & 178 & 96 & 82 & 6724 & 70.04 \\
\hline Total & 192 & & 0 & & 140.08 \\
\hline
\end{tabular}

Source: Author's field work, 2008

In table $4.4, \mathrm{X}^{2}$ computed $=140.08$. To determine the value of $\mathrm{X}^{2}$ from chi-square table.

Degree of freedom $(m)=n-1$

$2-1=1$

Assuming 0.01 level of significant $(99 \%$ confidence level $), X^{2}(0.01)=6.63$

Decision Rule

Accept the null hypothesis (Ho) of $\mathrm{X}^{2}$ computed $<\mathrm{X}^{2}$ table or reject the null hypothesis $\left(\mathrm{H}_{1}\right)$ of $\mathrm{X}^{2}$ computed $>\mathrm{X}^{2}$ table and accept the alternative hypothesis $(\mathrm{H}$,$) .$

\section{Conclusion}

Since computed $X>X$ table $(140.08>6.63)$ the alternative hypothesis $(H)$ which state that meaning physical development were carried out by the private investors should be accepted.

HYPOTHESIS THREE

Ho: There is no need for security network or facilities at port re-organized or totally replaced.

$\mathrm{H}_{1}$ : That there is need for more private sector involvement in Port operations and service.

Question Twelve:

From your assessment how is the present security network in the port

Table 4.5

\begin{tabular}{|l|l|l|}
\hline Option & Response & Percentage \\
\hline Efficient & $201(144.5)$ & 69.55 \\
\hline Not Efficient & $88(144.5)$ & 34.45 \\
\hline Total & 289 & 100 \\
\hline
\end{tabular}

Source: Author's field work, 2008

Considering table 4.5. option of efficient carries 69.55 percent in that the present security network of the port is efficient, that since the private investors has taken over the operations and services of terminals. This are respond from the Nigerian Post Authority staff and the private firms that won the terminals which include the indigenous and multinational institutions. 
The numbers in bracket in table 4.5 represent the expected frequencies.

The expected frequency $(\mathrm{E})=\mathrm{EX} / \mathrm{n}^{289} / 2=144.5$

The data in table 4.5 can be re-arranged to show the observed frequency (0), expected frequency (E), deviation (O-E), square deviation $(0-\mathrm{E} .)^{2}$

Table 4.6

\begin{tabular}{|l|l|l|l|l|l|}
\hline Options & 0 & E & O-E & $(\mathrm{O}-\mathrm{E})$ & $\mathrm{X}=(\mathrm{O}-\mathrm{E}) / \%$ \\
\hline Efficient & 201 & 144.5 & -56.5 & 3192.25 & 22.09 \\
\hline Not efficiency & 88 & 144.5 & $56 . .5$ & 3192.25 & 22.09 \\
\hline Total & 289 & & 0 & & 44.18 \\
\hline
\end{tabular}

Source: Author's field work, 2008

From the above table, the computed chi-square $\left(\mathrm{X}^{2}\right)=44.18$, so to determine $\mathrm{X}^{2}$ from the chi-square table (Appendix V)

Degree of freedom $(m)=n-1$

$2-1=1$

Assuming 0.01 level of significant $(99 \%$ confidence level) i.e X2 $(0.01,1)=6.63$ (Appendix V)

\section{Decision Rule}

Accept Null hypothesis (Ho) ifX2 computed $<\mathrm{X}^{2}$ of chi-square table or reject Null hypothesis $\left(\mathrm{H}_{\mathrm{o}}\right)$ if $\mathrm{X}^{2}$ computed $>\mathrm{X}^{2}$ of chi-square table and accept the alternative hypothesis $\left(\mathrm{H}_{1}\right)$

Conclusion

Since the computed $\mathrm{x}>\mathrm{X}$ of chi-square table (Appendix V) the null hypothesis $\left(\mathrm{H}_{\mathrm{o}}\right)$ is rejected, while the alternative hypothesis $\left(\mathrm{H}_{1}\right)$ is accepted which state that these is need for security network and/or facilities at the ports re-organized or totally replaced.

HYPOTHESIS FOUR

Ho: That there is no need for more private sector involvement in port operations and services.

$\mathrm{H}_{1}$ : That there is need for more private sector involvement in port operations and services.

Question Thirteen:

Would you like this more private sector involvement in port operations and services

Table 4.7

\begin{tabular}{|l|l|l|}
\hline Option & Response & Percentage \\
\hline Yes & $159(166.5)$ & 47.75 \\
\hline No & $174(166.5)$ & 52.25 \\
\hline Total & 333 & 100 \\
\hline
\end{tabular}

Source: Author's field work, 2008

In table 4.7 the total of three hundred and thirty three $\left(\begin{array}{ll}33 & 3\end{array}\right)$ response in which one hundred and seventy four (174) which made up of 52.25 percent of the respondent kick against more private investors and participation in port operations and services.

The expected frequency $(\mathrm{E})=\mathrm{EX} / \mathrm{n}=333 / 2=166.5$

The data in table 4.7 can be re-arranged to reflects the observed :frequency $(0)$, expected frequency (E), deviation (O-E), square deviation $(0-\mathrm{E})^{2}$

Table 4.8

\begin{tabular}{|c|l|l|l|l|l|}
\hline Options & 0 & $\mathrm{E}$ & $\mathrm{O}-\mathrm{E}$ & $(\mathrm{O}-\mathrm{E})$ & $\mathrm{X}=(\mathrm{O}-\mathrm{E}) / \%$ \\
\hline Yes & 159 & 166.5 & -7.5 & 56.25 & 0.34 \\
\hline No & 174 & 166.5 & 75 & 56.25 & 0.34 \\
\hline Total & 333 & & 0 & & 0.68 \\
\hline
\end{tabular}

Source: Author's field work, 2008

The computed $\mathrm{X}=0.68$ (table 4.8 ), so if degree of freedom $(\mathrm{m})=\mathrm{n}-1$

$2-1=1$

Assuming 0.01 level of significant (99\% confidence level) if Xoo1, = 6.63 (Appendix V)

\section{Decision Rule}

Accept Null hypothesis (Ha) if $\mathrm{X}$ computed $<\mathrm{X}^{2}$ of chi-square table and reject Null hypothesis $\left(\mathrm{H}_{\mathrm{o}}\right)$ if $\mathrm{X}$ computed $>\mathrm{X}^{2}$ of chi-square table and accept the alternative hypothesis $\left(\mathrm{H}_{1}\right)$

Conclusion

Since the computed $\mathrm{X}^{2}=0.68<\mathrm{X}^{2}=6.63$ of chi-square table (Appendix V). The Null hypothesis is accepted which state that these is no need for more private sector involvement in port operations and services and the alternative hypothesis $\left(\mathrm{H}_{1}\right)$ is rejected. 


\section{HYPOTHESIS FIVE}

$\mathrm{H}_{\mathrm{o}}$ : There has been no remarkable improvement in port operations and services by the private investors.

$\mathrm{H}_{1}$ : There has been remarkable in the operations and services by the private investors

Question Fourteen:

In your operations and services has there been any remarkable improvement? Table 4.9

\begin{tabular}{|l|l|l|}
\hline Option & Response & Percentage \\
\hline Yes & $86(48.5)$ & 88.66 \\
\hline No & $11(48.5)$ & 11.34 \\
\hline Total & $\mathbf{9 7}$ & $\mathbf{1 0 0}$ \\
\hline
\end{tabular}

Source: Author's field work, 2008

Datas in table 4.9 shows that 88.66 percent of 97 respondent agreed that there is remarkable improvement in port operations and services, one should know that the respondent are staff of private investors which include both the executive staff, the directors, and other cadre of the organization.

If expected frequency $=\mathrm{EX} / \mathrm{n}=97 / 2=48.5$

The above datas in table 4.9 can be re-arranged to reflects the observed frequency $(0)$, expected frequency $(\mathrm{E})$, deviation $(\mathrm{O}-\mathrm{E})$, and square deviation $(\mathrm{O}-\mathrm{E})^{2}$

Table 4.10

\begin{tabular}{|c|c|c|c|c|c|}
\hline Options & 0 & $\mathrm{E}$ & $\mathrm{O}-\mathrm{E}$ & $(\mathrm{O}-\mathrm{E})$ & $\mathrm{X}=(\mathrm{O}-\mathrm{E}) / \%$ \\
\hline Yes & 86 & 48.5 & 37.5 & 1406.25 & 15.49 \\
\hline No & 11 & 48.5 & -37.5 & 1406.25 & 14.49 \\
\hline Total & 97 & & 0 & & 28.98 \\
\hline
\end{tabular}

Source: Author's field work, 2008

The computed $\mathrm{X}^{2}=28.98$, if degree of freedom $(\mathrm{m})=\mathrm{n}-1$

$2-1=1$

Assuming 0.01 level of significant $\left(99 \%\right.$ confidence level) then $\mathrm{X}^{2} 0.01,=6.63$ (Appendix V)

\section{Decision Rule}

Accept Null hypothesis (Ho) if $\mathrm{X}^{2}$ computed $<\mathrm{X}^{2}$ of chi-square table

(Appendix V)

Reject Null hypothesis (Ho) if $\mathrm{X}$ computed $>\mathrm{X}^{2}$ of chi-square table and accept the alternative hypothesis $\left(\mathrm{H}_{1}\right)$ Conclusion

Since the computed $X^{2}=28.98>X^{2}$ of chi-square 6.63 (Appendix V), the null hypothesis is rejected while the alternative hypothesis $(\mathrm{H})$ is accepted, which state that there has been remarkable improvement in port operations and services by the concessionaires (private investors).

\section{SUMMARY OF FINDINGS}

Based on the research the government is displeasure of the state of port infrastructure and its operations: thus, the reform was a framework to reposition the seaports and the Nigeria economy at large. The seaport from its monopolist operation and to reduce or eliminate funding from the government limited financial resources; couple with the global trend of private participation in government enterprises.

In general, apart from the recent port reforms several of reforms has been carried out which affect the maritime sector, aim to relief government of financial burden, by so doing the following has taken place in the sector.

1. The 1996 ports Reforms: presently, the seaport industry is geared toward economic growth in that there is significant improvement on revenue generated. As a result, the elimination of wasteful expenditure resulting in saving of almost $\mathrm{N} 9$ billion, more so over $\$ 4.9$ billion has been realized from the terminal concession, a dividend of private sector initiative.

2. The passing and the implementation of Coastal \& Inland Shipping Act 2003, known as Cabotage Law.

3. The abolition of Pre-shipping, Inspection Scheme (PIS) of import to Nigeria and the introduction of Destination Inspection Scheme (DIS).

4. In the area of efficiency, the ship waiting time has been reduced from 14 to Zero day. Ship turn-around time has also reduced from 5 to 2 day and slight reduction in port charges.

Towards operations, the role of Nigerian Port Authority (NP A) and concessionaries are well spelt out. The NPA will regulate the activities of the concessionaires, see to the maintenance of superstructures. The NPA, will too enforce the Nigerian and international regulations, monitor performance of investors, maintain statistics on port performance, ensure that port infrastructures and superstructure are maintained accordance with agreement, see to the safety and security in port and compliance with internal and international environmental 
regulations.

Further findings shows that the investors shall under port reforms will maintain direct contact with the shipping line within the contact agreement without interference from the NPA. Moreso, the reform policy forced the seaport operators (private investors) to modernize their infrastructures and to build and install new equipment capable of providing least services demanded by port users. Finding also shows that the security trend in and around the seaports has taken different shape following fencing, lighting and employment of security personnel in line with the International Ships and Pott Security (ISPS) code and compliance. Despite of series of port reform to maximize the benefits derived from a coordinated and well functional seaport, the Nigerian seaport still being faced with number of problem. So in area of the inspection, the scheme is hindered by multiple and duplication of inspections by several government agencies. So the port users complains of misinterpretation of custom codes (cargo code), which result to huge charges and duties.

Finding shows that the re-allocation of cargoes especially, containers to designed terminal, crate problems to both the importers, inspection agent and the port security.

In addition, overlapping functions between the inspection agent, the security and NPA staff.

To sum it up seaport, the seaport has few numbers of scanning machines.

\section{SUGGESTED RECOMMENDATIONS}

This part of the research will be of help after studying the advantages and demerit of the reforms, as designed and pursued by the government. The suggested recommendations are drawn after extensively study of the terms of contract and administered questionnaires.

Based on the fact that the position to Nigeria economy is highly import base so it very important for Nigeria judges, legal practitioners and legal institutes to known the terms of contract and the legal framework of the port reforms, in case of discrepancies and/or disagreement.

In other to provide an efficient and to achieve the significant of the reform, infrastructure such as road and rail relatively need to be in good conditions and frequent maintenance of such transport infrastructures and to improve on environmental degradation. Furthermore, in the area of wage, salary and relevant benefit to the dockworkers, the government and the concerned labour organization and related labour unions should set international standard on this area. There should be good relationship between dockworkers and their employers to manimize workers unrest. More so, in term of training, the private investors needed to be monitored to ensure that the employees were trained and re-train time to time attain technology transfer and capacity building. Simultaneous inspection of cargo can be adopted, whereby separate inspections are allowed to reduce delay good clearance. Destination inspection companies need to install additional scanning machine to cope with volume of import. In addition, the financial institutions (Banks) needs to be up-doing to face the challenges in shipping industries, in the areas of timely processing of shipping document in their custody. Finally, whatever the case, relevant body(s) should ensure proper implementation of all the reforms and contract agreement white necessary legal instrument and framework to guide the seaport operations, so that the aims and objectives of the reforms are achieved while care must be taken to protect and preserve the overriding public interest in the flow of shipping business, commerce, nations economy and the security of the country at large

\section{CONCLUSION}

From the research and past records the Nigerian government owned manage and controlled enterprises has collapsed while the existing one are not doing well in its operation and services on why they were established, inclusive is the Nigerian seaports. The rationale behind port reforms in Nigeria is to improve on port best practice and services delivery, considering the challenges, involving private participation in seaport practice, from the above explanation, the seaports needs a reform to compete with other seaport in the region and the world at large.

So far so good, several port reform from 1996 was a strategies aimed to improve on maritime economy and its activities based on this, all stakeholders, the supervising bodies and agents should be committed to the reform. Furthermore, the government should ensure that the reform encourage capacity building, security of the nation economy while care must be taken so that the reform never mortgage and bargaining future economy of the nation. Finally, as much as the reforms are concerned, private operators must be compelled to fulfil their obligations not only regarding services conditions and charges but also regarding equipment maintenance, safety, services quality and any other matters that will be of multiply effect to the nation economy at large.

Selected Bibliography

Adeniyi, Kunle (2000): "Transport Challenges in Nigeria in the next two decades". Transport study unit, NISER Ibadan

Afolayan (2000): "The Impact of Commercialization on Port Performance in Nigeria". A study of Lagos Port. An unpublished M.Sc Thesis. OlabisiOnabanjo University Ago-Iwoye, Nigeria 
Agbakoba, O.(2001) "Legal and regulatory frame work of concessioning". In port operations, seminar paper presented at workshop on increasing private sector participation in port operations 19" 11" July, 2001, Lagos Nigeria

Badejo, Dele (1998): Maritime Transport in Nigeria. Rex Charles Publication, Abeokuta

Chikwe, K. (1999): "Nigerian Port to be Commercialized soon" Maritime Watch, Quarterly December 1999, Lagos, Nigeria

Dangote, A (2002): "Private-Public Collaboration in the Nigeria Ports Industry".

Paper presented at a National workshop on Survival Strategies in the maritime industry 24th June, 2002. Lagos, Nigeria Pp 2

Ekong, B.U ( 1986): "Shipping and its effects on the Nigeria Economy; Improving Shipping and Port Performance in Nigeria" Ola Bangbose Press \& Co Lagos.

Maduekwe, 0. (2002): "Achieving Ports Sector Reform through Private Sector Participation". A Nigeria Ports Authority Commercialization. A vital option for survival. A Publication f Nigerian Port Authority

Nigeria Ports Authority: Legal Agreement: Container: Terminal at Apapa Port, 2005. Nigeria Ports Authority: Yearly Statistic Report, 2005

Smaggle (2000): "Port Reform". Worldwide experience. A paper presented at World

Bank Transport Sector Workshop 3rd -4th April, 2000 Abuja, Nigeria Pp 11 